\title{
Methuselah 900 years Old Variant Time Flow in the Old Treatment
}

\section{Paul TE Cusack*}

Independent Researcher, Saint John NB, Canada

Submission: January 13, 2018; Published: May 15, 2018

*Corresponding author: Paul TE Cusack, Independent Researcher, BScE, DULE, 1641 Sand y Point Rd, Saint John, NB, Canada E2K 5E8, Tel: (506) 214-3313; Email: St-Michael@hotmail.com

\section{Abstract}

Here is a brief paper that examines the physics behind the extreme life spans of the Bible such as methuselah and Noah. There is a near perfect correlation of the plot of these ages vs. the generations from Adam. The Bible can be believed with certainty. The Ancients understood Physics better than we did until now.

Keywords: Patriarchs; Energy-time parabola; Clairnaut; Regression; Gravitation constant; Energy; Time; Parabola; Variant; Ridiculous; Correlation; Nostradamus; Astrotheology

\section{Introduction}

Many of scientific mind reject the Bible because of seemingly ridiculous things such as three life span of the patriarchs. It seems to defy common sense and thus the entire Bible is reject, and faith in God along with it. I show here that our previous understanding of the Bible was incorrect; the ancients had it right. It was just that modern scientists did not know that time doesn't flow constantly. It varies with the golden mean parabola. In this paper, I examine that life pan recorded in the Hebrew
Scriptures and how that fits in with my previous theory on AstroTheology. Christians need not apologize for such "ridiculous "things as Methuselah living to be 000 years old [1].

\section{Energy - Time Parabola}

We know that the Energy -time parabola describes the flow of time which is not constant. It follows the Golden mean equations: $t^{\wedge} 2-t-1=0$ (Figure 1 ).

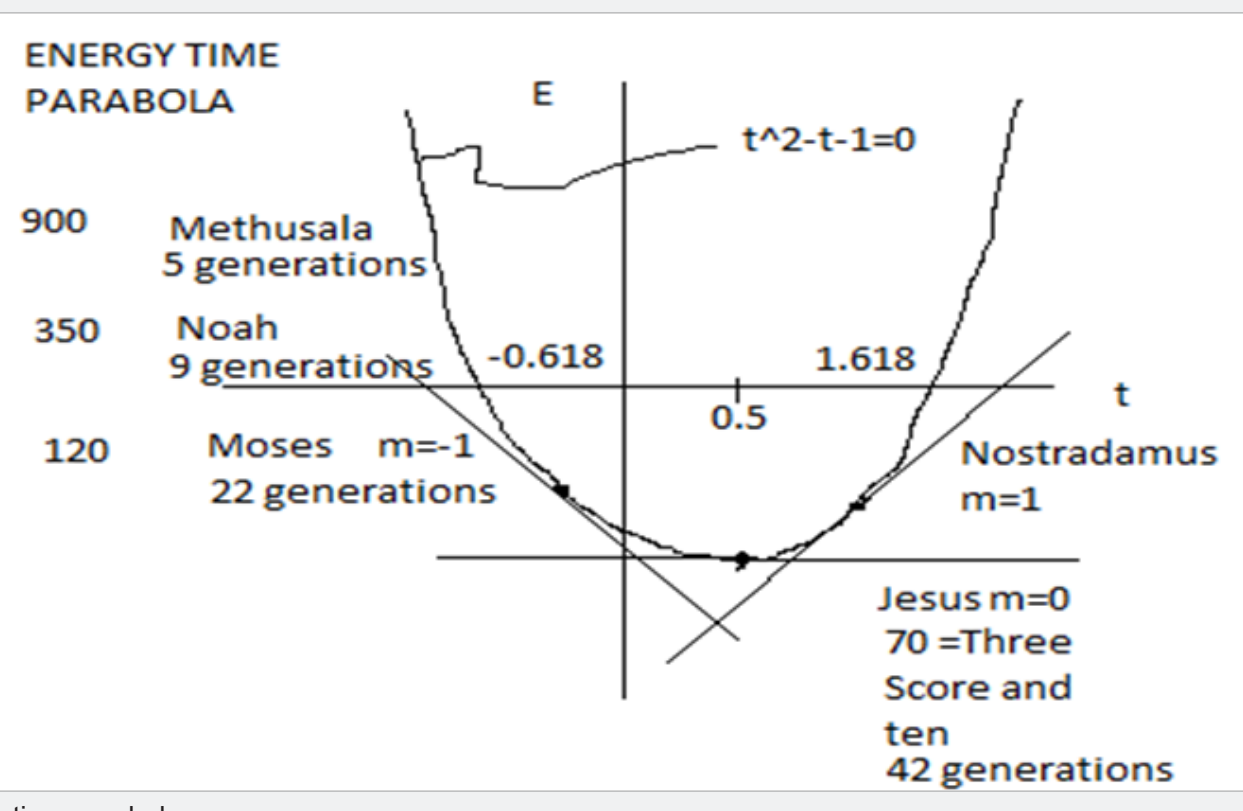

Figure 1: Energy -time parabola. 


\section{Global Journal of Archaeology \& Anthropology}

If we take the derivative of this parabola, we get the equation: $2 \mathrm{t}-1=\mathrm{C}$.

Since, as I have explained in a previous paper [1] that Jesus entered time at the bottom, (or minimum Energy) level of the parabola, then we can see who entered time at when $\mathrm{dE} / \mathrm{dt}=1$. They were Moses on the left of the minimum, and Nostradamus on the right side of the parabola. Moses lived to be 120 years old. There are two other people, Methuselah and Noah, who we know how many generations they descended from Adam. And we know how long they lived. Methuselah lived to be 900 years old; and Noah lived to be 350 years old.

We know from my paper on Astrotheology [2], that the universe exists where the function equals the derivative. This means that the velocity, $v$ and the acceleration a are equal. $S=v=a$ [3]. If we consider only Methuselah, Noah Moses and Jesus, we see that as the generations from Adam to this patriarch increase, their life span decreases. In fact, I calculate that it is not that their life span increase, but that time flowed more quickly as we go back to Adam. See the following table for a comparison of the generations vs. The life span is shown in Table 1.

Table 1: Comparison of the generations vs. the life span.

\begin{tabular}{|c|c|c|}
\hline Patriarch & Generations & Life Span \\
\hline Methusalah & 5 & 900 \\
\hline Noah & 9 & 350 \\
\hline Moses & 22 & 120 \\
\hline Jesus & 42 & 70 \\
\hline
\end{tabular}

Refer to Matthew 1 Luke 3 for a genealogy of Christ from Adam. There are $14 \times 3$ generations from Adam to Jesus. Moses was a Levite, son of Jacob (Israel).Psalm 90:10 records that a man will live "three score and ten" i.e., 70 years (Table 2) (Figure 2).

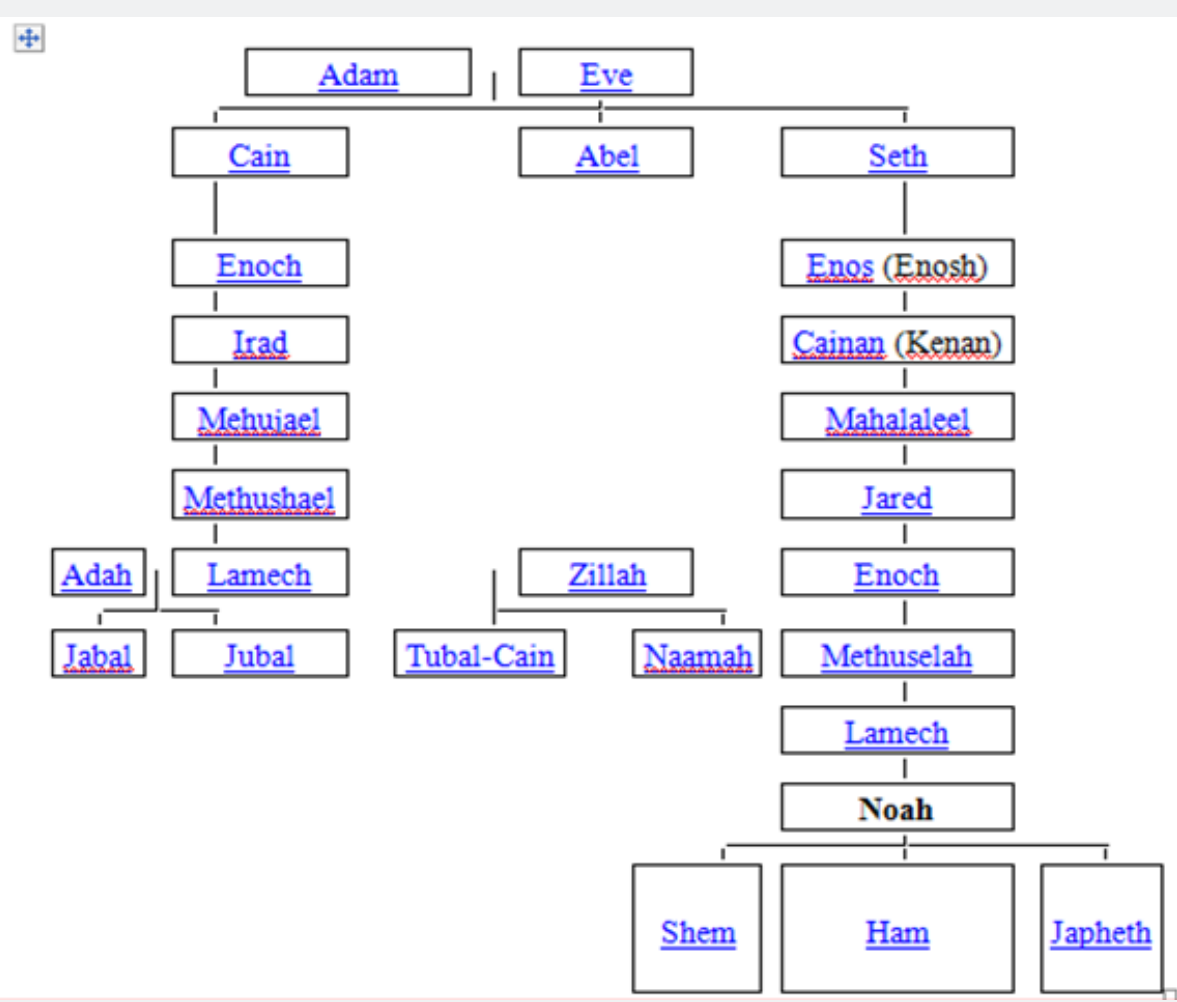

Figure 2: Methuselah an Noah from Adam.

Table 2: 14 × 3 generations from Adam to Jesus. Moses was a Levite, son of Jacob (Israel). Psalm 90:10 records that a man will live "three score and ten" i.e., 70 years.

\begin{tabular}{|c|c|c|c|c|}
\hline Patrirch & Derivative= 2t-1 & Time & Slope $\mathbf{m}=\mathbf{d x} / \mathbf{d y}$ & Distance $\mathbf{D}=\mathbf{1} / \mathbf{2}$ at ${ }^{\wedge} \mathbf{2}$ \\
\hline Methusalah & 2.24 & -0.618 & 0.4324 & 0.5 \\
\hline Noah & -1.618 & 0.909 & 0.7282 & 0.809 \\
\hline Moses & -1 & 0 & 1.232 & 1.1125 \\
\hline Jesus & 0 & 0.5 & 1.9973 & 1.9896 \\
\hline
\end{tabular}


Since we know that the universe follows the Clairnaut Differential Equation, $d^{\wedge} 2 E / d t^{\wedge} 2-G=0$, if we take the Integral, we have

$$
\begin{aligned}
& \delta E / \delta \mathrm{t}-\mathrm{G}=\mathrm{C} \\
& \text { Or } \\
& \mathrm{E}=\mathrm{y}=\mathrm{y}=\mathrm{y}^{\prime \prime} \\
& \mathrm{Y}=\mathrm{y}^{\prime \prime} \\
& \mathrm{Y}=\mathrm{y}^{\prime} \\
& \text { Ln } \mathrm{t}=1 / \mathrm{t}
\end{aligned}
$$

We also know from Astrotheology that $E=1 / \mathrm{t}$

$E=1 / t$

So, $\operatorname{Ln} \mathrm{t}=1 / \mathrm{t}$

Ln $\mathrm{t}=\mathrm{E}$

$\mathrm{E}=1 / \mathrm{t}$

Therefore, $\mathrm{E}=\mathrm{t}$

Ln $\mathrm{t}=\mathrm{t}$

Next, we take the Ln of $x$ and $y$, or E and t (Table 3).

Table 3: Straight line with $\mathrm{R}^{\wedge} 2$ correlation coefficient.

\begin{tabular}{|c|c|c|c|c|}
\hline Patrirach & $\mathbf{T}^{\wedge} \mathbf{2 - t - 1 = E}$ & Ln E=X & Generations & Ln G=Y \\
\hline Methusalah & 19 & 2.94 & 5 & 6.80 \\
\hline Noah & 71 & 4.26 & 9 & 5.85 \\
\hline Moses & 461 & 6.13 & 22 & 4.78 \\
\hline Jesus & 1721 & 7.45 & 42 & 3.73 \\
\hline
\end{tabular}

If we plot these $(X, Y)$ pairs, we get a nearly perfect straight line with $\mathrm{R}^{\wedge} 2$ correlation coefficient,

\section{$\mathrm{R}^{\wedge} 2=0.9962$ Perfect $=1$}

The equation is interesting. It is $\mathrm{Y}=-0.656 \mathrm{x}-8.71$

Note the Gravitational Constant, without nuclear forces, $\mathrm{G}=6.52=\mathrm{Pi} / \mathrm{Ln} 1.618$

Sample size: 5

Mean x ( $\bar{x}): 4.762$

Mean y ( $\bar{y}): 5.592$

\begin{tabular}{|c|c|}
\hline \multicolumn{2}{|c|}{ Best-fit values } \\
\hline Slope & $-0.6648 \pm 0.02902$ \\
\hline Y-intercept & $8.744 \pm 0.1588$ \\
\hline $\mathrm{X}$-intercept & 13.15 \\
\hline 1/Slope & -1.504 \\
\hline \multicolumn{2}{|c|}{ 95\% Confidence Intervals } \\
\hline Slope & -0.7896 to -0.5399 \\
\hline Y-intercept & 8.060 to 9.427 \\
\hline $\mathrm{X}$-intercept & 11.86 to 15.03 \\
\hline \multicolumn{2}{|l|}{ Goodness of Fit } \\
\hline R square & 0.9962 \\
\hline Sy.x & 0.1002 \\
\hline \multicolumn{2}{|l|}{0020} \\
\hline \multicolumn{2}{|c|}{ Is slope significantly non-zero? } \\
\hline $\mathrm{F}$ & 524.9 \\
\hline DFn, DFd & 1,2 \\
\hline P Value & 0.0019 \\
\hline Deviation from horizontal? & Significant \\
\hline \multicolumn{2}{|c|}{ Data } \\
\hline Number of XY pairs & 4 \\
\hline Equation & $Y=-0.6648^{*} X+8.744$ \\
\hline
\end{tabular}

Intercept (a): 8.7170242134747

Slope (b): -0.65624195999049

Regression line equation: $\mathrm{y}=8.7170242134747$ 0.65624195999049x (Figure 3) (Table 4).
Table 4: Best-fit values.

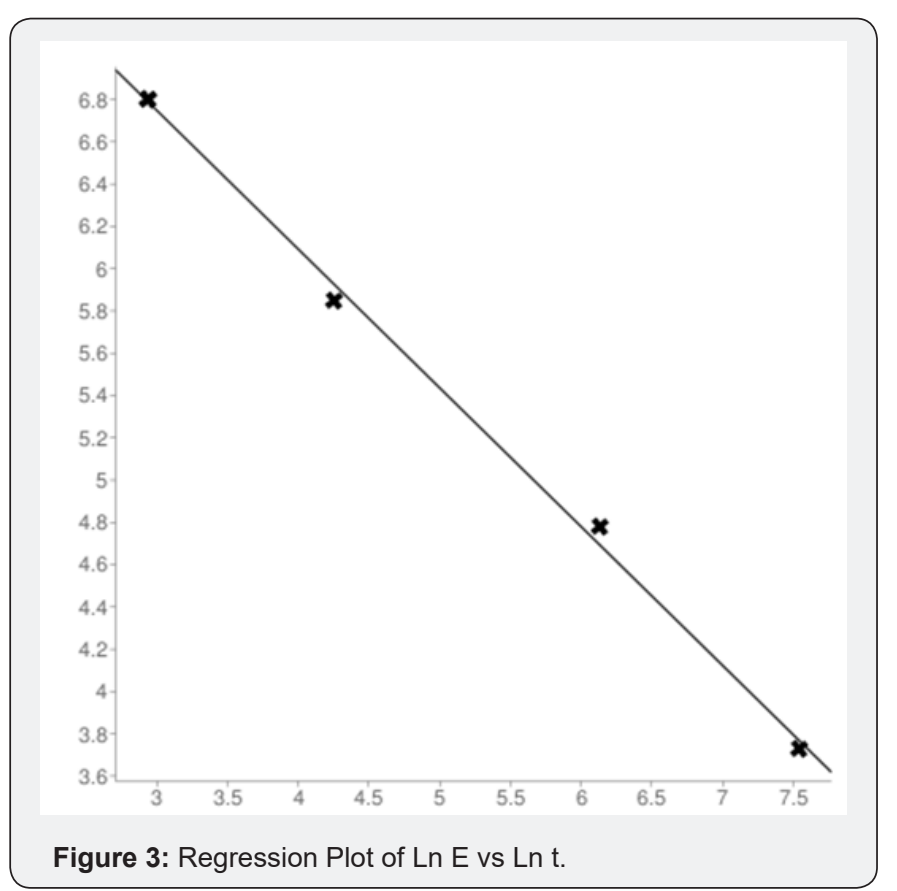




\section{Conclusion}

In conclusion, we see that the exorbitant life spans of patriarchs such these do make sense. Belief in the Truth of the Bible cannot and should not be discarded because of trouble with our present understanding $[4,5]$. We also see that the ancient Hebrew civilization knew about the Astrotheology Physics which is more advanced than that which we know until now.

\section{References}

1. Cusack P (2016) Time Travel for Nostradamus.

2. Cusack P (2016) Astrotheology. Cusack's Universe, J of Physical Mathematics OMI Jan.

3. Cusack P, Ancient Egyptian Mathematics.

4. Cusack P, The Bible Code and AstroTheology.

5. Cusack P (2015) The Hebrew Civilization. LULU.

\section{Your next submission with Juniper Publishers} will reach you the below assets

- Quality Editorial service

- Swift Peer Review

- Reprints availability

- E-prints Service

- Manuscript Podcast for convenient understanding

- Global attainment for your research

- Manuscript accessibility in different formats

( Pdf, E-pub, Full Text, Audio)

- Unceasing customer service

Track the below URL for one-step submission https://juniperpublishers.com/online-submission.php 